\title{
THE RELATIONSHIP OF MONEY ETHICS ON TAX EVASION WITH INTRINSIC RELIGIOSITY, EXTRINSIC RELIGIOSITY, AND MATERIALISM AS MODERATING VARIABLES (CASE ON PRIVATE TAXPAYERS LISTED IN KPP PRATAMA TERNATE)
}

\author{
Resmiyati Ansar ${ }^{1}$, Suriana A. R Mahdi ${ }^{2}, \mathrm{Wa} \mathrm{Susi}^{3}$ \\ ${ }^{1,2,3}$ Accounting Study Program, Economics and Business Faculty, Khairun University, Jl. Jusuf \\ Abdurrahman, Ternate, 97719, Indonesia
}

Corresponding e-mail : anto.tox7969@gmail.com

\begin{abstract}
This study aims to find out the influence of money ethics on tax evasion with intrinsic religiosity, extrinsic religiosity, and materialism as moderating variables. The sample is selected by using convinience sampling method with sample size of a 100 respondents as primary data. This study uses simple regression and moderated regression analysis for hypothesis testing. The result of this study shows that money ethics has an effect on tax evasion, intrinsic religiosity moderarates the relationship between money ethics and tax evasion. Extrinsic religiosity does not moderate the relationship bertween money ethics and tax evasion. Materialism moderates the relationship between money ethics and tax evasion. Keywords: money ethics, intrinsic religiosity, extrinsic religiosity, materialism, tax evasion JEL Classification : H24, H26
\end{abstract}

Article info:

Received 29 November 2018

Revised 18 December 2018

Accepted 24 December 2018

Available online 31 December 2018

\section{INTRODUCTION}

The advances of taxation system by countries normally followed economic growth. These phenomenons also exist in Indonesia because tax revenue is the main contributor for financing the state expenditures. The importance of taxation makes Directorate General of Taxes takes routine dissemination for the knowledge of taxation through formal education, training of taxation in higher education institutions, and taxation news. Much of taxpayers are misleading to fulfill their tax obligation because they are uninformed about the tax rules or regulations which are getting more complex (Halim et al. 2014).

The tax itself establishes in Law No. 16 of year 2009 which concern about General Provisions and Tax Procedures. Tax is a mandatory contribution to the state owed by an individual or entity that is compelling based on the law by not getting direct compensation and used for the state's needs for the greatest prosperity of the people. The function of tax is to provide the highest contribution in state revenues, approximately 60 to 70 percent of total tax revenues to meet the state budget posture. The taxes plays significant role for the State Budget because tax is one of the sources of government revenue to finance routine expenditures and development expenditures for the welfare of society. The tax function is included as the budgetair function. This function aims to increase as much the state cash receipts as possible in order to finance central and regional government spending and development. Therefore, the government continues to try to increase the source of revenue that comes from tax. This is done by filling in the State Budget in accordance with the predetermined tax revenue target. However, according to the Directorate General of Taxes 
lately the revenue from the tax sector has increased but is not as targeted by the government. So that state expenditure is not optimal which results in not smooth state development as planned by the government (Halim et al. 2014).

An indication that the tax revenue target is not achieved because practice of tax evasion by taxpayers. Tax evasion is an action that has been revealed lately that is mostly done by taxpayers and tax officials. This can be seen from the many tax evasion cases that appeared in the mass media. The motives carried out by individuals in carrying out tax evasion vary and the amount of money that is perverted has considerable value. Various kinds of statements have sprung up, including taxpayers who do not report all their income, as well as tax wage cooperation cases between tax officers and taxpayers (Suminarsi and Supriyadi, 2012).

The phenomenon of tax evasion cases in Ternate City is value added tax evasion cases (VAT) of 1.9 billion and income tax (PPh) of 2.6 billion carried out by taxpayers in PDAMs from 2012 to 2015, as well as tax evasion 1.7 billion motorized vehicles carried out by taxpayers in Samsat (One Roof Single Administration System) in 2014 (www.deiknews.com/2015 Sekot and Tempo.co/kejatimalut). This has attracted the attention of this study to examine the causes of tax evasion. One of reasons for not achieving the tax revenue target is due to taxpayers' actions that minimize their taxes through various methods and one of it is the tax evasion. Tax evasion is the illegal manipulation of the taxation system to avoid paying taxes or tax evasion is the neglect of deliberate tax laws and regulations to avoid paying taxes, such as counterfeiting tax returns (Halim et al. 2014).

Previous studies about the influence of money ethics on tax evasion with intrinsic religiosity and extrinsic rerigiusitas as moderating variables have been carried out. The study of Lau et al. (2013) in Malaysia shows that there is a positive relationship between the ethics of money and tax evasion, and the higher the individual's intellectual religiosity has a positive impact on the relationship of ethical money with tax evasion whereas extrinsic religiosity does not have a significant effect. Consistently, the study of Rosianti and Mangoting (2014) in West Surabaya shows that ethics of money has a positive effect on tax evasion while intrinsic religiosity as a moderating variable managed to moderate the relationship between ethical money and tax evasion whereas extrinsic religiosity does not succeed in moderating this relationship.

Ramadani (2016) shows that ethical money and extrinsic religiosity has positive effect on tax evasion but intrinsic religiosity has no effect on tax evasion. Ramadani (2016) confirms that intrinsic and extrinsic relationship of religiosity as a moderating variable it did not succeed in moderating the relationship between ethics of money towards tax evasion. Basri (2014) shows that there is a negative relationship between etiaka money and tax evasion, and the higher the individual's intrinsic religiosity will have a positive impact on the relationship of ethical money with tax evasion whereas extrinsic religiosity does not have a significant effect. Basri (2015) shows that there is a positive relationship between the love of money and the ethics of tax evasion, while religiosity does not affect the ethics of tax evasion. Dharma (2016) shows that there is no influence between religiosity on the perception of tax evasion.

According to Hafizhah (2016) in addition to money ethics, religiosity and gender, another variable that influences individual ethical attitudes towards tax evasion is materialism. His research says materialism moderates the effect of ethical money on tax evasion. People who have materialism tend to have the desire to have a lot of money means having a high ethic of money towards money, a high level of ethical money towards money will reduce moral ethics, making it possible to do tax evasion. The results of research conducted by Hafizhah (2016) show that money ethics has a significant positive effect on tax evasion with religiosity, gender and materialism as moderating variables. However, the 
research conducted by Basri (2014) shows different results, namely that the ethics of money has a negative influence on tax evasion, religiosity, and gender as a moderating variable. While the results of Ramadani's study (2016) show that money ethics and extrinsic religiosity have a positive effect on tax evasion, but intrinsic religiosity has no effect on tax evasion. In the intrinsic and extrinsic relationship of religiosity as a moderating variable it did not succeed in moderating the relationship between ethics of money towards tax evasion.

The inconsistency of the results of previous studies which suggested the positive influence of ethics of money on tax evasion and also the negative influence of the ethics of money on tax evasion. There are also results of research that show religiosity moderates the relationship between ethics of money and tax evasion and also religiosity that does not moderate the relationship between ethics of money and tax evasion, the researchers are motivated to conduct research again on the effect of ethical money on tax evasion with intrinsic religiosity, extrinsic religiosity and materialism as a moderating variable. This study replicates from the study of Rosianti and Mangoting (2014) which located in West Surabaya. The differences for this study with reference are as follow: first, the differences in the location and time of research conducted by Rosianti and Mangoting in West Surabya (2014), while the location and time of this study is in Ternate City (2017); Both researchers added one moderating variable namely materialism according to the recommendations in the journal referred by this study; The three previous studies did not use theory and researchers used two theories, namely Theory of Planned Behavior and Contingency, and there were still many research gaps or gaps between the variables that researchers adopted from previous research, and this study is still rarely studied, especially at the Primary Tax Office in Ternate.

\section{LITERATURE REVIEWS}

The grand theory of this study is the Theory of Planned Behavior (TPB) which is related to the variable Money and Middle Theory Ethics used is Contingency Theory that supports intrinsic religiosity variables, extrinsic religiosity and materialism, and Applied Theory which used by previous studies. Theory of Planned Behavior (TPB) is an extension of the Theory of Reasoned Action (TRA). TRA explains that a person's intention towards behavior is formed by two main factors, namely attitude toward the behavior and subjective norms (Ajzen and Fishbein, 1975) whereas, in TPB one more factor was added, namely perceived behavioral control (Ajzen, 1991). Based on the TPB model, it is explained that individual behavior to disobey tax provisions is influenced by intention to behave noncompliant, such as embezzling taxes. Theory of Planned Behavior (TPB) states that in addition to attitudes toward behavior and subjective norms, individuals also consider perceived behavioral control, namely their ability to carry out these actions, Ajzen (1991).

The relevance of tax evasion behavior with this theory is that if the taxpayer considers that tax evasion is a bad thing (negative attitude) and surrounding individuals who are considered important or role models assume that the behavior of tax evasion should not have been carried out, then the intention will behave not embezzling taxes and then can become behavior. The main factor in this theory is the individual's intention to carry out a behavior where the intention is indicated by how strong the desire to try or how much effort is made in carrying out the behavior. Generally, the greater the individual's intention to behave, the greater the behavior is achieved or implemented (Ajzen, 1991).

The contingency approach in organizational behavior is different environment that causes different behaviors. Contingency theory motivates the analysis of the situation before taking action and eliminating the usual behavior based on assumptions about behavior. Thus, contingency theory can be used for all the latest knowledge about the organization in the most appropriate way depending on situational variables. To reconcile conflicting studies findings, contingency approach is needed to evaluate conditional factors. The effect of ethical 
money on tax evasion has contingency factor, the factors in question are intrinsic religiosity, extrinsic religiosity and materialism. These 3 factors are moderating variables that can strengthen or weaken the influence of ethical money and tax evasion (Govindarajan, 1986).

Tax evasion. Tax evasion is an effort made by taxpayers to reduce the tax burden paid in a way that violates the law. Taxpayers relieve the tax costs that must be paid in an unethical manner by ignoring the applicable tax provisions, falsifying documents, or filling in incomplete and incorrect data. Tax evasion is very detrimental to the state because it can reduce substantial state revenues. In the implementation of tax collection, the government applies strict laws and regulations, so that the implementation of taxes must be carried out properly and correctly. This is done to minimize the opportunity for taxpayers to carry out tax evasion. Taxpayers themselves have the opportunity to reduce the tax burden without breaking the rules, one of them is by way of tax avoidance (Mardiasmo, 2009). Research on tax evasion which has been investigated by McGee (2006), found that tax evasion has three views, namely: Tax evasion is considered never ethical, tax evasion is seen as always ethical.

Money ethics. Money ethics is a person's perception and interpretation of money. Money is one of the most important aspects in everyday life. Subjectly, the ethics of money have many meanings depending on the individual perceptions of each. Based on management on individual level, money is very important with individual attitudes both positive and negative attitudes that can be seen through personality, biology, and attitude variables (Mitcheell and Mickel, 1999 in Mangoting, 2014). Tang (2002) said that the ethics of one's money have a significant and direct influence on unethical behavior. This shows that individuals who have a high ethic of money will place money as an important thing that will lead to a less ethical and sensitive attitude compared to individuals who have low money ethics. So that by having a lot of money, someone has a higher satisfaction needs and can enjoy a better standard of living. Therefore, they try to make more money to maintain their lifestyle. High money ethics motivates individuals to engage in unethical behavior, one of which is tax evasion. Because of the importance of money and its different interpretations, Tang (1992) introduced the concept of high money ethics. The theory seeks to measure one's subjective feelings about money. High money ethics will place individuals on a big interest in money and think money is everything in life. Tang et al. (2005) argued that ethical attitudes toward money learned through the socialization process were established in childhood and maintained through adult life. Individuals who have high ethics of money, they will put a higher interest in money. These individuals tend to see things with money. High money ethics will cause individuals to take unethical actions, namely tax evasion because they do not want to carry out their obligations to pay taxes. Because tax is considered a burden and tax evasion is considered to be an ethical action that can be done (Basri, 2014). According to Tang et al. (2000) that mental health of a professional with a low level of ethical money has a low job satisfaction and vice versa. Tang and Chiu (2003) theorize that high money ethics is closely related to the concept of "greed". Where employees with high levels of ethics of money are less satisfied with their work compared to their peers and express a direct relationship between high ethical money and unethical behavior among employees in Hong Kong.

Religiosity. According to McDaniel and Burnett (1990) religiosity is belief in God accompanied by a commitment to follow the principles believed to be established by God, religiosity is different from spirituality. Spirituality provides meaning, unity, relevance to nature, humans and transcendence whereas religiosity provides teachings and narratives that encourage individual morality. Religiosity is activities related to religion. Individual moral reasoning will shape the character caused by beliefs in the religion he adheres to, Glover (1997). Allport (1967) argues that religion plays a role in the lives of individuals, who say that extrinsic character is the exterior role of religion for social support or even individual satisfaction, while intrinsic roles are strong internal guarantees for religion as part of the daily 
lives of individuals. Therefore, extrinsic religiosity is suggestive of having a religion to support various interests such as business interests, whereas intrinsic religiosity is an indication of religious commitment, spiritual purpose. Strong religious beliefs are expected to prevent illegal behavior through feelings of guilt especially in terms of tax evasion. It not only explores the effects of the presence of tax evasion in the Church, but also measures affiliation as an index of the importance of religion.

Materialism. Materialism is a material factor closely related to welfare, so material will always be the primary thing sought by individuals. Although material factors also support life welfare, but if the individual is fully oriented to the material it can lead to dissatisfaction, because they always want more than what has been achieved. It relates to the satisfaction that materialism is negatively correlated with some centers of life satisfaction, namely satisfaction with life as a whole, income, family life, pleasure in life, and friends (Maneo, 2014). The concept of developing the scale of materialism as a value that guides the choices for individuals and can be applied in various situations, including consumptive situations but not limited to this situation. The scale includes three components, namely acquisition as the main goal in life, acquisition as an effort to pursue happiness, and ownership reflects success (Richins and Dawson, 1992). Materialism refers to worldly assets which are considered to occupy a central part of one's life and are believed to be the greatest source of satisfaction and dissatisfaction (Belk, 1985). Tandon et al. (2011) state that highly materialistic individuals have tendencies show values and attitudes which are opposite to social sensitivity and social impact. So from that it can be concluded that materialistic individuals will tend to refuse if they have to deal with moral ethics and corporate social responsibility (CSR), and this is inversely proportional to individuals who are not materialistic.

\section{Hypotheses development}

The relationship of tax evasion to money ethics. Money is one of the most important aspects of everyday life and is often used to measure success. Money ethics is a different perception and interpretation of individuals on money (Tang, 2002). Based on management literature which concludes that at the individual level, money is very important with individual attitudes relevant to the theory of planned behavior which explains the central factor of individual behavior is that behavior is influenced by individual intentions towards certain behaviors. While the intention to behave is influenced by attitude variables, subjective norms and perceptions of individual behavior control in interpreting money and can trigger the individual to behave positively and negatively which can be seen through his personality (Ajzen, 1991). If the individual interprets money in positive terms, he will use the money as needed and will be satisfied with what he has or vice versa. Where the individual will use money as he pleases and never feels satisfied with what he gets is called high money ethics. This can encourage individuals to behave unethically namely to commit tax evasion, such as income tax evasion and value added tax, as well as motor vehicle tax carried out by individual taxpayers in Ternate City. The study of Hafizhah (2016) concluded that ethics of money has a positive effect on tax evasion. This study supports previous research conducted by Lau et al. (2013); Rosianti and Mangoting, (2014); Ramadani (2016) which states that ethics of money has a positive effect on tax evasion. High money ethics tend to cause individuals to have low moral ethics behavior and think that tax evasion is ethical and tends to be done, such as tax evasion (Lau et al. 2013). The higher the ethics of someone's money towards money, the obligation to pay taxes will be felt quite heavy to do, so that the person will make an effort so that his tax obligations become lower by doing various things, which can lead to tax evasion behavior. The study of Basri (2014) shows that money ethics is negatively related to tax evasion. Where the higher the ethics of money, the more likely the individual to behave unethically is to commit tax evasion. High money ethics is closely 
related to greed (Tang and Chiu, 2003). Based on the description of previous research, the formulation of the hypothesis proposed is:

H1: money ethics affects the tax evasion.

The relationship of ethical money to tax evasion with religiosity as moderator. Religiosity is trust by committing to follow the principles that are believed and established by Allah SWT. Extrinsic religiosity is suggestive of individuals having religion as an excuse in business interests whereas intrinsic religiosity is an indication of religious commitment and for spiritual purposes (McDaniel and Burnett, 1990). Contingency theory described by Govindarajan (1986) states that organizational or individual behavior can be determined by a combination of internal and external forces in certain environmental situations, where intrinsic religiosity possessed by an individual is something that comes from within and is a personality trait possessed by an individual. The higher the stage of individual religiosity, the more the individual pays attention to broader and more universal interests than his personal interests. This is different from extrinsic religiosity whose influence comes from outside the individual in accepting and practicing the teachings of his religion. Extrinsic religiosity is describing selective religious beliefs, or sorting out religious teachings according to primary needs and always associating them with other self-centered interests (McDaniel and Burnett, 1990). High money ethics will affect individuals to commit tax evasion, such as income tax and value added tax that occur in Ternate City. Strong intrinsic religiosity can control individual behavior to act more ethically. Therefore, with high religiosity in individuals, it can have a positive influence on the relationship between the ethics of money and tax evasion. Where the intrinsic religiosity of the individual is stronger, it can prevent ethical behavior of money that can encourage individuals to commit unethical behavior, namely tax evasion. Strong religious beliefs prevent illegal behavior through feelings of guilt especially in terms of tax avoidance, Grasmick (1991) in Basri (2014). The results of the Hafizhah (2016) study concluded that intrinsic religiosity moderates the relationship of ethical money with tax evasion, but extrinsic religiosity is not able to moderate the relationship of ethical money with tax evasion. This study supports previous research conducted by Lau et al. (2013); Basri, (2014); Rosianti and Mangoting, (2014) which states that intrinsic religiosity moderates the relationship of money ethics with tax evasion, but extrinsic religiosity is not able to moderate the relationship of ethical money with tax evasion. While the study of Ramadani (2016) shows different results stating that the ethics of money and extrinsic religiosity influence tax evasion, while intrinsic religiosity has no effect. In the relationship of intrinsic and extrinsic religiosity as a moderating variable did not succeed in moderating the relationship between ethics of money towards tax evasion. Based on the description of previous inconsistent research, efforts are needed to reconcile inconsistencies by identifying the conditional factors between the two variables with the contingency approach (Govindarajan, 1988), the hypotheses formulated are folow:

H2: Intrinsic religiosity moderates the influence of money ethics on tax evasion.

H3: Extrinsic religiosity moderates the influence of money ethics on tax evasion.

The relationship of ethical money ethics to tax evasion with materialism as moderator. Materialism reflects a set of beliefs relating to the importance of acquiring and possessing objects (things) in life (Richins and Dawson, 1992). Dynamic individual behavior sometimes claims the absence of the best way to control individual attitudes statically and to analyze situations that are always dynamic, contingency theory is needed to reconcile diverse individual behaviors, in order to evaluate conditional factors related to the attitude of individual materialism to the relationship between ethics of money with tax collection. Where the same thing requires an effort to explain the relationship between variables, it must view moderation as one of the schemes to conceptualize conformity with the contingency approach (Govindarajan, 1988). The results of the research by Richins and Dawson (1992) describe 
that materialism has a negative correlation with some centers of life satisfaction, namely satisfaction with life as a whole, income, family life, pleasure in life, and friends. While Tandon et al. (2011) states that individuals who are very materialistic will tend to show values and attitudes that are contrary to sensitivity to social and social impacts and thus these individuals will have a negative attitude towards CSR. This relates to the contingency theory described (Govindarajan, 1986) states that knowledge that is final about the organization depends on situational that occurs in the environment of the organization or individual. So it can be concluded that materialistic individuals will tend to refuse if they have to deal with ethics and Corporate Social Responsibility (TJSP) inversely with individuals who are not materialistic. The study of Hafizhah (2016) shows there is relationship of money ethics and tax evasion with materialism as moderator. The attitude of materialism tends to cause individuals to have low moral ethics. It means that the higher the attitude of materialism, the more likely it is to make a deviation namely tax evasion will increase. From other previous studies, the hypothesis proposed by the researcher is as follows:

H4: Materialism moderates the influence of the ethics of money on tax evasion.

\section{RESEARCH METHOD}

\subsection{Data}

The type of data used in this study are primary data which obtained from questionnaires that have been answered by the respondent in writing from the Individual Taxpayers registered at the Tax Service Office (KPP) of Pratama, Ternate City. The technique of data collection is done by distributing questionnaires directly to individual taxpayers registered at Ternate Primary KPP who were sampled in this study.

\subsection{Sample}

The population for this study is individual taxpayers registered with the KPP Pratama Kota Ternate, which amounted to 84,271 individual taxpayers. The reason of this study to choose Individual Taxpayers as respondents because the reality that was rampant in carrying out tax evasion was individual taxpayers, such as income tax evasion, value added tax and motor vehicle taxation that occurred in the PDAM and in Ternate City Samsat. The criteria used are individual taxpayers registered at the Pratama Tax Service Office (KPP) of Ternate. For the research design the method used to calculate the sample is the Slovin Method (Kurniawan, 2014) whose formula is as follows:

$$
\mathrm{n}=\frac{\mathrm{N}}{1+}
$$

where, $\mathrm{n}$ is sample amount, $\mathrm{N}$ is population, and $\varepsilon^{2}$ is error which tolerated 0.1 . Based on population for 84,271 individual taxpayers, the sample is

$$
\mathrm{n}=\frac{84,271}{1+84,271 \cdot(0.1)^{2}}=99,74 \text { or } 100 \text { (rounded up) }
$$

\subsection{Method of analysis}

The method of data analysis in this study is simple regression analysis for the first model, while the Moderate Regression Analysis (MRA) to test the second model hypothesis to the fourth model is done partially moderated by interaction tests between independent variables and moderating variables with the help of SPSS 16 program (Ghozali, 2013). The model of this study noted as follows. 


$$
\begin{array}{lll}
\mathrm{Y}=\beta_{0}+\beta_{1} X_{1}+\beta_{2} Z_{1}+\beta_{3} X_{1} Z_{1}+\varepsilon_{2} & \mathrm{H}_{2} \\
Y=\beta_{0}+\beta_{1} X_{1}+\beta_{2} Z_{2}+\beta_{3} X_{1} Z_{2}+\varepsilon_{3} & \mathrm{H}_{3} \\
Y=\beta_{0}+\beta_{1} X_{1}+\beta_{2} Z_{3}+\beta_{2} X_{1} Z_{3}+\varepsilon_{4} & \mathrm{H}_{4}
\end{array}
$$

\subsection{Variable definitions}

Tax evasion $(Y)$. Tax evasion is an illegal act that is carried out by not paying part or all of the tax debt borne by violating the applicable tax regulations. Tax evasion is measured using a Likert scale in the form of a questionnaire consisting of 3 item statements with 3 indicators namely the Tax System, Tax Justice, and Discrimination adopted from Basri (2014). The scale used to measure tax evasion is a five-point Likert scale which are 1 (strongly disagree) to 5 (strongly agree).

Money ethics $\left(X_{1}\right)$. Money ethics are different views and interpretations of each individual in assessing the meaning of money in his life. This scale measures human attitudes towards money. Money ethics is measured using a Likert scale in the form of a questionnaire consisting of 5 item statements with 5 indicators: good, evil, achievement, self-confidence and satisfaction, adopted from Basri (2014). The measurement scale of money ethics using a 5-point Likert scale, namely 1 (strongly disagree) to 5 (strongly agree).

Intrinsic religiosity $\left(Z_{1}\right)$. Individuals who have intrinsic religiosity are people who consider their religion to be the purpose of life where this individual is committed that religion is the real guide to life. Intrinsic religiosity is measured using a Likert scale in the form of a questionnaire consisting of 5 item statements with 3 indicators which are: personal, fullness of appreciation, and association (Allport and Ross, 1967), and adopted from Basri (2014). The scale used to measure the intrinsic religiosity variable is the five-point Likert scale, namely 1 to 5 .

Extrinsic religiosity $\left(Z_{2}\right)$. Individuals who have extrinsic religiosity are individuals who use their religion to achieve their own goals, such as individuals who go to places of worship with the aim of social status. Extrinsic religiosity was measured using a Likert scale in the form of a questionnaire consisting of 5 item statements with 5 indicators: Institutional, Instrumental, Communal, Peripheral and causal attention to faith development (Allport and Ross, 1967). Extrinsic religiosity was measured using a questionnaire adopted from Basri (2014). The scale used to measure extrinsic religiosity variables is a five-point Likert scale, namely 1 (strongly disagree) to 5 (strongly agree).

Materialism $\left(Z_{3}\right)$. Materialism is reflecting a belief that is concerned with the importance of acquiring and possessing objects (goods) in life (Richins and Dawson, 1992). Materialism is a view that contains the attitudes, beliefs, and values of life that emphasize and prioritize the ownership of goods and material wealth above other life values, such as religious, intellectual, social and cultural values. Materialism is measured using a Likert scale in the form of a questionnaire consisting of 5 item statements with 3 indicators, namely: success, centralization and welfare in life adopted from Tang, Choe and Tan (2013). The scale used to measure materialism variables is a five-point Likert scale, namely 1 (strongly disagree) to 5 (strongly agree).

\section{RESULTS AND DISCUSSIONS}

\subsection{Results}

Result of hypothesis and model interpertations. Hypothesis testing uses the test of the coefficient of determination $\left(\mathrm{R}^{2}\right)$ which is determined by the value of Adj. $\mathrm{R}$ Square and $\mathrm{t}$ statistical test (partial testing) at significance of 0.05 or $5 \%$. Furthermore, testing simple regression for hypothesis model 1, and testing models 2 through 4 use the interaction test (multiplying two independent variables) or called the Moderated Regression Analysis (MRA) with the partial moderation statistical test (Ghozali, 2013). 
Testing of Model 1. The first hypothesis examines the effect of ethical money on tax evasion. A simple regression equation is done by using a partial test and interpreting the numbers that are in the unstandardized beta coefficient. Table 1 presents the results of testing of Model 1.

Table 1. Result of simple regression

\begin{tabular}{lccc}
\hline \multirow{2}{*}{ Independent Variable } & \multicolumn{2}{c}{ Dependent variable : Tax evasion } \\
\cline { 2 - 4 } & Coefficient & t & Sig. \\
\hline Constant & 3,765 & 2.623 & 0,010 \\
Money ethics & 0,209 & 2,359 & 0,020 \\
& & & \\
Adjust R Square & 0,044 & & \\
F stattistics & 5,567 & & \\
Sig. & 0,020 & & \\
\hline Sig & & &
\end{tabular}

Source : Proceeds data, 2018

Based on Table 1 the model of this study is follows:

$\mathrm{Y}=3,765+0,209 \mathrm{X}_{1}+\varepsilon$

Based on the regression result, the constant is 3.765 means that if money ethics is worth 0 then tax evasion has a constant value of 3.765. The coefficient of money ethics is 0.209 indicates that if money ethics increase for $1 \%$ then tax evasion will increase by 0.209 assuming other variables are considered constant. Adjusted R Square $\left(\mathrm{R}^{2}\right)$ value in Table 1 is 0.044 or $4.4 \%$, which means that $4.4 \%$ of tax evasion is influenced by the variable of money ethics while the remaining $95.6 \%$ is influenced by other variables besides the variables used in this study. The test results in Table 1 show that the p-value (significance) of 0.020 is smaller at a significant level of $0.05(0.020<0.05)$. This shows that the money ethics affects tax evasion and $\mathrm{H}_{1}$ is accepted.

Testing of Model 2. The second hypothesis testing intrinsic religiosity moderates the relationship of money ethics to tax evasion. Table 2 presents the test results using partial moderation statistics using the following Moderated Regression Analysis (MRA) equation.

Table 2. Result of Moderated Regression Analysis

\begin{tabular}{lccc}
\hline \multirow{2}{*}{ Independent Variable } & \multicolumn{3}{c}{ Dependent variable : Tax evasion } \\
\cline { 2 - 4 } & Coefficient & t & Sig. \\
\hline Constant & 5,693 & 9,695 & 0,000 \\
Money ethics & $-0,419$ & $-9,225$ & 0,000 \\
Moderator 1 & 0,043 & 22,391 & 0,000 \\
& & & \\
Adjust R Square & 0,843 & & \\
F stattistics & 267,666 & & \\
Sig & 0,000 & & \\
\hline Source:Proceds & &
\end{tabular}

Source : Proceeds data, 2018

Based on Table 2, a partial moderation model can be made that includes the original type of moderation (pure moderation), where the moderating variable $(Z)$ does not function as an independent variable and is not related to the dependent variable, but directly interacts with the independent variable $(\mathrm{X})$, from the interaction it was immediately revised to see the interaction between the independent variables and the dependent variable using the following Moderated Regression Analysis (MRA) equation:

$\mathrm{Y}=5,693-0,419 \mathrm{X}_{1}+0,043 \mathrm{Z}_{1}+\varepsilon$ 
The constant is 5.693 indicates that if the moderating variable 1 is 0 then tax evasion has a constant 5.693. The coefficient of money ethics is -0.419 indicates that if it increases $1 \%$, then tax evasion will decrease -0.419 in assumption that other variables are constant. The regression coefficient on the contraction between intrinsic religiosity variables and money ethics is 0.043 . This illustrates if there is an increase in the moderating variable 1 by $1 \%$, then tax evasion will increase by 95.7 assuming other variables are considered constant. Adjusted $\mathrm{R}$ Square $\left(\mathrm{R}^{2}\right)$ value in Table 2 shows the determinant coefficient or variation role (independent variable in relation to the dependent variable) of 0.843 which means that $84.3 \%$ variation in tax evasion can be explained by the interaction between money ethics and intrinsic religiosity while the remainder is $15.7 \%$ is explained by other variables outside of this research model. The calculated $\mathrm{F}$ value in Table 2 is 267,666 with a significance value of 0,000 . This can be interpreted that the equation model used in this study is appropriate because the significance value is $<0.05$. The test results in Table 2 show that the p-value (significance) for the money ethics variable is 0,000 , while the interaction between the money ethics variables and 0,000 smaller intrinsic religiosity is significant at $0.05(0,000<0,05)$. Based on the statistical results presented in Table 2 for model 2 shows intrinsic religiosity moderates the relationship between money ethics and tax evasion, thus $\mathrm{H}_{2}$ is accepted.

Testing of Model 3. The third hypothesis examines extrinsic religiosity which moderates the relationship between money ethics and tax evasion. The test results use statistically partial moderation (partial effects) using the Moderated Regression Analysis (MRA) equation which will be presented in Table 3 below:

Table 3. Result of Moderated Regression Analysis

\begin{tabular}{lccc}
\hline \multirow{2}{*}{ Independent Variable } & \multicolumn{3}{c}{ Dependent variable : Tax evasion } \\
\cline { 2 - 4 } & Coefficient & t & Sig. \\
\hline Constant & 3,575 & 2,469 & 0,015 \\
Money ethics & 0,129 & 1,093 & 0,277 \\
Moderator 2 & 0,006 & 1,010 & 0,315 \\
& & & \\
Adjust R Square & 0,044 & & \\
F stattistics & 3,294 & & \\
Sig & 0,041 & & \\
Soun $:$ Proceeds & &
\end{tabular}

Source : Proceeds data, 2018

Based on Table 3, a partial moderation model can be made which includes the original type of moderation (pure moderation), where the moderating variable $(\mathrm{Z})$ does not function as an independent variable and is not related to the dependent variable, but directly interacts with the independent variable $(\mathrm{X})$, from the interaction it was immediately revised to see the interaction between the independent variables and the dependent variable using the following Moderated Regression Analysis (MRA) equation:

$$
\mathrm{Y}=3,575+0,129 \mathrm{X}_{1}+0,006 \mathrm{Z}_{2}+\varepsilon
$$

The constant is 3.575 indicates that if the moderating variable 2 is 0 , then tax evasion has a constant value of 3.575. The coefficient of ethical budget variable is 0.129 indicating that if the ethics of money increases by $1 \%$, then tax evasion will increase by 0.129 assuming other variables are considered constant. The coefficient on the interaction of extrinsic religiosity and ethics money variables is 0.006. This illustrates that if there is an increase in the moderating variable 2 by $1 \%$, then tax evasion still has a value of 0.006 assuming other variables are considered constant. Adjusted R Square (R2) value in Table 3 shows the determinant coefficient or variation role (independent variable in relation to the dependent variable) of 0.044 which means that $4.4 \%$ variation in tax evasion can be explained by the 
results of the interaction between money ethics and extrinsic religiosity, while the remaining $95.6 \%$ is explained by other variables outside the research model. The calculated $\mathrm{F}$ value in Table 3 is 3.294 with a significance value of 0.041 . This can be interpreted that the equation model used in this study is correct because the significance value is below 0.05 . The test results in Table 3 show that the p-value (significance) for the money ethics variable is 0.277 , while the interaction between the ethics of money and extrinsic religiosity of 0.315 is greater at a significant level of $0.05(0.277>0.05$ and $0.315>0.05)$, so that the statistical results presented in Table 3 for model 3 show hypothesis 3 , extrinsic religiosity does not moderate the relationship between ethical money and tax evasion thus $\mathrm{H}_{3}$ is rejected.

Testing of Model 4. The fourth hypothesis tests materialism which moderates the relationship between money ethics and tax evasion. Table 4 presents the test results of partial moderation statistics with the Moderated Regression Analysis (MRA).

Table 4. Result of moderated regression analysis

\begin{tabular}{lccc}
\hline \multirow{2}{*}{ Independent Variable } & \multicolumn{3}{c}{ Dependent variable : Tax evasion } \\
\cline { 2 - 4 } \multicolumn{1}{c}{ Constant } & Coefficient & t & Sig. \\
Money ethics & 6,826 & 7,547 & 0,000 \\
Moderator 3 & $-0,481$ & $-6,361$ & 0,000 \\
& 0,038 & 12,955 & 0,000 \\
Adjust R Square & & & \\
F stattistics & 0,646 & & \\
Sig & 91.437 & & \\
\hline Source: Proceeds & 0,000 & & \\
\end{tabular}

Source : Proceeds data, 2018

Based on Table 4, a partial moderation model can be created which includes the type of pure moderation where the moderating variable (Z) does not function as an independent variable and does not relate to the dependent variable but directly interacts with the independent variable $(\mathrm{X})$. to see the interaction between the independent variable and the dependent variable using the following Moderated Regression Analysis (MRA) equation:

$\mathrm{Y}=6,826-0,481 \mathrm{X}_{1}+0,038 \mathrm{Z}_{3}+\varepsilon$

The constant is 6.826 indicates that if the moderating variable 3 is 0 , then tax evasion has a constant value of 6.826. The regression coefficient on the ethics of money variable is -0.481 indicating that if the ethics of money experiences a $1 \%$ increase, then tax evasion will decrease by -0.481 assuming other variables are considered constant. The regression coefficient on the interaction of variables between ethical money and materialism is -0.481 . This illustrates if there is an increase in moderation variable 3 by $1 \%$, then tax evasion will decrease by -0.481 assuming other variables are considered constant. Adjusted R Square (R2) value in Table 4 shows the determinant coefficient or variation role (independent variable in relation to the dependent variable) of 0.646 , which means that $64.6 \%$ variation in tax evasion can be explained as moderating variable3, while the remaining $35.4 \%$ is explained by other variables outside of this research model. The calculated $F$ value in Table 4 is 91.437 with a significance value of 0.000 . This can be interpreted that the equation model used in this study is appropriate because the significance value is $<0.05$. The test results in Table 4 show that the p-value (significance) for the money ethics variable is 0,000 , while the moderating variable 3 is 0,000 smaller at a significant level of $0.05(0,000<0,05)$. Based on the statistical results presented in Table 4 for model 4, the $\mathrm{H} 4$ hypothesis is accepted which states that materialism is able to moderate the relationship between ethics of money and tax evasion. 


\subsection{Discussions}

Effect of money ethics on tax evasion. The results of this study indicate that money ethics as an independent variable partially has a significant effect on tax evasion. One of the factors, due to the interpretation of the majority of respondents answering the statements in the questionnaire, agrees with the temporary assumptions of the researcher, where ethics of money is able to explain the effect on tax evasion. This means that the high and low ethics of money that individuals have will affect the occurrence of tax evasion or can be said by individuals with high money ethics will tend to do tax evasion because the individual views tax evasion as ethical to do so increases the occurrence of tax evasion. Individuals have an ethical attitude to money, which is the top priority is money and considers the practice of tax evasion as a reasonable action (Rosianti and Mangoting, 2014). This research is in line with the concept of money ethics proposed by Tang and Chiu (2003) who views that high money ethics is the root of crime that is very strong in relation to "greed" which directs individuals to unethical behavior and is also relevant to the Theory of Planned Behavior explained that individual behavior to obey or disobey tax provisions is influenced by intention, subjective norms, and individuals also consider perceived behavioral control, namely the ability of an individual to take an action (Ajzen 1991). This study shows that the ethics attitude of money results in behavior such as dissatisfaction that causes fraud (Tang, 1992). This is in line with the reality in the case of value added tax evasion (PPN) and income tax (PPH) carried out by individual taxpayers in the PDAM from 2012 to 2015, as well as motor vehicle tax evasion in Samsat (One Roof Single Administration System) in 2014 in Ternate City. The results of this study are consistent with research (Lau et al., (2013); Rosianti and Mangoting, (2014); and Hafizhah (2016) who find that ethics of money influences tax evasion.

Intrinsic Religiosity Moderates the Relationship of Money Ethics on Tax Evasion. The results of this study indicate intrinsic religiosity moderates the relationship between ethical money and tax evasion. This means that if the individual's intrinsic religiosity gets higher, it will increase and have a positive impact on the relationship of money ethics with tax evasion. In this case the intended impact is the presence of high intrinsic religiosity can reduce the ethical attitude of money and can improve individual moral ethics so that they can minimize the desire of individuals in carrying out unethical actions namely tax evasion (Mcdaniel, 1990). Individuals who have a high ethical attitude tend to behave unethically such as tax evasion. When individuals have a strong intrinsic religiosity attitude in themselves, they will not be affected in behaving unethically, because religious values and norms are the main consideration in behaving, because strong religious commitments and beliefs can prevent unethical actions through guilt to Allah SWT. This is relevant to the concept of intrinsic religiosity which states that individual moral behaviors will shape the character caused by beliefs in the religion they embrace (Glover, 1997). The results of this study are also relevant to contingency theory which explains the contingency approach in motivating behavior where there is a situation or conditional analysis before taking action, where the individual behaves in accordance with the existing situation (Govindarajan, 1986). It is known that moderating variable of intrinsic religiosity does not function as an independent variable and is not related to the dependent variable, but directly interacts with the independent variable (X), the interaction of the moderating variable between money ethics and intrinsic religiosity is significantly related to the tax evasion which means intrinsic religiosity is a pure moderation variable (Ghozali, 2013). The results of this study are consistent with the studies of Lau et al. (2013), Rosianti, Mangoting and Basri, (2014), and Hafizhah (2016) which show that intrinsic religiosity is able to moderate relationship between money ethics and tax evasion.

Extrinsic religiosity moderates the relationship of money ethics on tax evasion. The results of this study indicate extrinsic religiosity does not moderate the relationship of ethical money with tax evasion. This means that the high and low extrinsic individual religiosity 
does not increase or influence the relationship between the ethics of money and tax evasion. This is because individuals who have an extrinsic religious orientation tend to use religion for their own purposes with the aim of worshiping only to meet relationships and fulfill their own interests, even those individuals are motivated to use their religion for personal gain (Allport and Ross, 1967). The rationale that researchers mean is that individual behavior in the context of tax evasion is a way to justify oneself that is carried out by taxpayers when carrying out tax evasion behavior that aims to reduce guilt or assume that fraud is an ethical act. The rationalization of individuals will certainly affect the extrinsic religiosity of the individual. The existence of high extrinsic religiosity cannot certainly influence the relationship between ethics of money and tax evasion. Therefore, based on the results of the study it can be explained that extrinsic religiosity does not affect the relationship between ethics of money and tax evasion. This happens because most individuals when viewed from the mean values in descriptive statistics assume that tax evasion is ethical to do where most individuals perceive that tax evasion can be seen as ethical action because the tax funds that they have collected will only be wasted and do not get any benefits or rewards from the taxes they pay and will only be corrupted by the government (Suminarsasi and Supriyadi, 2012). This condition is caused by individuals who do not want to pay taxes to governments that are corrupt or in other words the government has not allocated tax-sourced funds appropriately. So that the individual chooses the income he earns to be used for other personal purposes. When individuals feel that their income is not enough to meet their needs even though taxation has met the requirements both objectively and subjectively to pay taxes, then the individual does not want to pay taxes, because the individual pays tax does not get direct contravention of him. So, any external religious teachings have no effect in the relationship between the ethics of money and tax evasion. The characteristic of extrinsic religiosity is to develop religion selectively or sort religious teachings according to their personal needs (Block, 1993). The results of this study are relevant to the concept of religiosity which states that individual moral behaviors will shape the character caused by beliefs in the religion they embrace (Glover, 1997). The results of this study are relevant to contingency theories that explain contingency approaches in diverse and dynamic individual behaviors, motivating situation or conditional analysis before taking action (Govindarajan, 1986). And the principle of this study is consistent with the research (Lau et al., (2013); Rosianti; Mangoting and Basri (2014); and Hafizhah (2016) which shows that extrinsic religiosity is not able to moderate the relationship between ethics of money and tax evasion.

Materialism moderates the relationship of money ethics to tax evasion. The results of this study indicate materialism moderates the relationship between ethical money and tax evasion. This means that the high and low attitudes of materialism possessed by individuals will influence the relationship of ethical money with tax evasion. Where the higher the materialism of individuals, the higher the ethics of individual money which causes moral ethics to be lower which will motivate these individuals to commit irregularities (Hafizhah, 2016), such as cases of value added tax evasion (VAT), income tax (PPh) and tax on motorized vehicles in the PDAM and in the Samsat of Ternate City. The results of this study are relevant to the concept of materialism which explains that materialistic individuals will have a tendency to show values and attitudes that are contrary to sensitivity to social and social impacts and thus the individual will have low moral ethics which means the higher attitude of materialism hence the desire to do tax evasion also increases (Hafizhah, 2016). This research is relevant to contingency theory which explains the contingency approach in motivating behavior. There is a situation or conditional analysis before taking action, where individuals in behaving adjust to existing circumstances and situations (Govindarajan, 1986). The results of this study are consistent with the research of Hafizhah (2016) which shows that materialism influences and moderates the relationship between ethics of money and tax 
evasion. The moderating materialism variable does not function as an independent variable and is not related to the dependent variable, but directly interacts with the independent variable $(\mathrm{X})$, the interaction of moderating variables between money ethics and materialism is significantly related to tax evasion variables, so it can be concluded that materialism variables are pure moderation variables (Ghozali, 2013).

\section{CONCLUSIONS}

This study concludes that: (1) Money ethics has a significant effect on tax evasion; (2) Intrinsic religiosity moderates the effect of the relationship between ethical money and tax evasion; (3) Extrinsic religiosity does not moderate the influence of the relationship between ethical money and tax evasion; (4) Materialism moderates the influence of the relationship between ethics of money and tax evasion. The limitations of this study are as follow: (1) Value of Adjust R Square ethics of money in this study is only a few percent which is able to explain tax evasion, meaning there is a greater influence than other variables that have not been explained in this study; (2) The variables used are still limited so that this study cannot explore various factors that can affect tax evasion; (3) The use of Slovin method in this study is less effective because the high and low population of the study will produce a number of samples that remain unified. Unless the research population under one respondent is still worthy of using this Slovin method; and (4) Proof of the hypothesis in this study only uses partial moderation (partial effect).

This study suggests that: (1) Further research is recommended to expand the scope of research objects, such as corporate taxpayers; (2) Future studies should add the number of independent variables that affect tax evasion such as tax discrimination, tax service quality, appropriateness of allocations, information technology, or different norms and cultures; (3) For further research you should use other methods in determining samples such as purposive sampling; and (4) Future studies should use partial moderation (partial effects) and simultaneous moderation (simultaneous effect), in order to see the results of both models of proof of the hypothesis.

\section{REFERENCES}

Ajzen, I., dan Fishbein, M. 1975. Attitudinal and normative variables as predictors of specific behaviors. Journal of Personality and Social Psychology.

Ajzen, Icek. 1991. The Theory of Planned Behavior. Organizational Behavior and Human Decision Processes. Vol 5, pp.179-211

Allport, G. W., dan Ross, J. M. 1967. Personal Religious Orientation and Prejudice, Journal of Personality and Social Psychology. 5: 447-457.

Basri, Yesi Mutia. 2014. "Efek Moderasi Religiusitas Dan Gender Terhadap Hubungan Etika Uang dan Kecurangan Pajak”. Simposium Nasionl Akuntansi.

Belk, R.W. 1985. "Materialism: Trait Aspects of Living in the Material World", Journal of Consumer Research, Vol. 12: 265-280.

Block, W. 1993. Public Finance Texts Cannot Justify Government Taxation: A Critique. Canadian Public Administration Publique in Canada. 36 (2): 225-262.

Ghozali, Imam. 2013. Aplikasi Analisis Multivariate dengan Program IBM SPSS 21 Badan

Penerbit Universitas Diponegoro. Semarang.

Glover, R. J. 1997. Relationships in moral reasoning and religion among members of conservative, moderate, and liberal religious groups. The Journal of Social Psychology. 137: 247-254. 
Govindarajan, V. 1986. Impact of participation the budgetary process on Managerial attitudes and performance Universalistic and Contingency perspectives. Strategic Management Journal in press.

Hafizhah, Ihsanul. 2016. Pengaruh Etika Uang Terhadap Penggelapan Pajak Dengan Religiusitas, Gender, dan Materialisme Sebagai Variabel Moderasi. Jom fekon. Vol.3 No.1. Februari 2016.

Halim, Abdul., Icuk Rangga Bawono dan Amin Dara. 2014 . Perpajakan: Konsep, Aplikasi, Contoh dan Studi Kasus. Selemba Empat. Yogyakarta.

Kurniawan, Albert. 2014. Metode Riset Untuk Ekonomi \& Bisnis: Teori, Konsep \& Praktik Penelitian Bisnis (Dilengkapi Perhitungan Pengolahan Data Dengan IBM SPSS 22.0). Alfabeta. Bandung.

Lau, Teck-Chai, Kum-Lung Choe. dan Luen-Peng Tan.. 2013. The Moderating Effect of Religiosity in the Relationship between Money Ethics and Tax Evasion. Journal of International Accounting, Auditing and Taxation 17 (2008), 67-78. Mardiasmo. 2009. Perpajakan. Edisi Revisi 200. Yogyakarta. Penerbit Andi.

McDaniel, S. W. dan Burnett, J. 1990. Consumer religiosity and retail store evaluative criteria. Journal of the Academy of Marketing Science. 18 (2).

McGee, R. W. 2006. Three views on the ethics of tax evasion. Journal of Business Ethics. $67: 15-35$.

Ramadani, Riska Febriana. 2016. Intrinsic dan Extrinsic Religiosity Sebagai Pemoderasi Hubungan Antara Money Ethics terhadap Tax Evasion. Thesis. Universitas Stikubank. (Tidak Dipublikasikan).

Richins, M. L. dan Dawson, S. 1992. A Consumer Values Orientation For Materialism and Its Measurement: Scale Development and Validation. The Journal of Consumer Research, Vol. 19. No. 3. Halaman 303-316.

Rosianti Camelia dan Yenny Mangoting. 2014.Pengaruh Money Ethics terhadap Tax Evasion dengan Intrinsic dan Extrinsic Religiosity sebagai Variabel Moderating. Journal Tax \& Accounting Review. Vol. 4. No.1, 2014.

Suminarsasi, Wahyu dan Supriyadi. (2012). Pengaruh Keadilan, Sistem Perpajakan, dan Diskriminasi terhadap Persepsi Wajib Pajak Mengenai Etika Penggelapan Pajak (Tax Evasion). Journal Proceeding Simposium Nasional Akuntansi XV. Banjarmasin.

Tandon, A. K., Mishra, S. K., dan Singh E. 2011. What Discriminates the Perspective Manager's Attitude Towards Corporate Social Responsibility? An Insight from Psychological Variables. The IUP Journal of Corporate Governance. Vol. 10, No.3. 52-70.

Tang, T. 1992. The Meaning of Money Revisited. Journal of Organization Behavior. Vol. 13 pp. 197-202.

Tang, T. L. P., Kim, J. K., dan Tang, D.S.H. 2000. Does Attitude Towards MoneyModerate the Relationship Between Instrinsic Job Satisfaction and Voluntary Turnover? Human Relations. Vol. 53 (2): 213-245.

Tang, T. L. P. 2002. Is the Love of Money the Root of All Evil? Or Different Strokes for Different Folks : Lessons in 12 Countries. Paper Presented to the International Conference on Business Ethics in the Knowledge Economy. Hongkong.

Tang, T. L. P. dan Chiu, R. K. 2003. Income, Money Ethic, Pay Satisfaction, Commitment, and Unethical Behaviour : Is the Love of Money the Root of Evil for Hongkong Employees? Journal of Business Ethics. 46: 13-30.

Tang, T. L. P., Tang, D. S.H., dan Luna-Arocas, R. 2005. Money Profiles: the love of money, attitudes, and needs. Personnel Review. Vol. 34 No.5, pp. 603. 